\title{
LETTERER-SIWE'S SYNDROME : REPORT OF A CASE WITH UNUSUAL PERIPHERAL BLOOD CHANGES
}

\author{
BY \\ N. P. ORCHARD, M.B., B.S. \\ From St. James Hospital, Balham, London
}

(Received for Publication, December 20, 1949)

In 1933 Siwe laid down the criteria of the syndrome now called Letterer-Siwe disease, and in the literature before and after that date the different features are discussed and related to the reported cases. The following case illustrates in particular the peripheral blood changes which may occur in this condition, and a table is appended summarizing the clinical and pathological features of 18 cases beginning with Letterer's (1924) case and bringing the series up to date (1950) with the present case.

\section{Case Report}

A boy aged $3 \frac{1}{2}$ years was admitted on March 11, 1948, with a history of soreness of the right ankle, anorexia, insomnia, and screaming in the night. The temperature was normal. The child was very pale and had puffy eyes. Firm and discrete nodes approximately $0.75 \mathrm{~cm}$. in diameter were palpable in the neck, especially in the posterior triangle, the axillae, and the groins. The tip of the spleen was easily palpable but there was some doubt about the liver being palpable. The right ankle was swollen but there was no tenderness and the movements were neither limited nor painful.

A radiograph of the chest showed a doubtful hilar shadow; the skull, humeri, pelvis, femora, tibiae and fibulae were normal.

Blood Count:

Haemoglobin, $44 \%$ (Haldane).

R.B.C., 2,300,000 per c.mm. W.B.C., 7,000 per c.mm.

Differential white count: neutrophil polymorphs, $4 \%$ (280 per c.mm.), lymphocytes, $95 \%$ (6,650 per c.mm.), haemohistiocytes, $1 \%$ (70 per c.mm.).

A tentative diagnosis of aleukaemic lymphatic leukaemia was made. During the next fortnight the temperature ranged from $90^{\circ}-100^{\circ} \mathrm{F}$. and a mass became palpable in the left iliac fossa.

28.3.48. Sternal puncture was performed. In the marrow films haemohistiocytes dominated the picture. Very few mature lymphocytes, granulocytes, and normoblasts were to be seen.
29.3.48. Intramuscular penicillin $(20,000$ units fourhourly) was started.

Wassermann reaction ++ ; Kahn reaction, strong positive.

Volmer patch test negative after $\mathbf{4 8}$ hours.

Total serum protein $5.55 \mathrm{~g}$. $\%$. $\begin{array}{lll}\text { Albumin } & 3.83 & \text { g. } \% \text {. } \\ \text { Globulin } & 1.72 & \text { g. } \% \text {. }\end{array}$

Albumin/globulin ratio $2 \cdot 2: 1$.

The father's and mother's Wassermann and Kahn reactions were negative.

Transfusion of 1 pint of packed cells.

6.4.48. Wassermann ++ ; Kahn, strong positive.

7.4.48. Penicillin dosage increased to 50,000 units four-hourly.

11.4.48. Wassermann and Kahn tests negative.

Paul Bunnell test negative.

22.4.48. Penicillin discontinued.

20.5.48. X-ray examination of the humeri, pelvis, femora, tibiae, and fibulae showed no abnormality.

26.5.48. Transfusion of 1 pint of blood. The spleen was easily palpable but not the liver, owing to guarding in the right hypochondrium. By percussion the liver was found to be enlarged two fingerbreadths below the costal margin.

17.6.48. Biopsy of a lymph node from the posterior triangle.

18.6.48. Liver palpable now.

19.6.48. Child vomited a few ounces of bright blood.

20.6.48. Occult blood in the stools. Transfusion of 1 pint of packed cells. Patient now running a hectic temperature.

24.6.48. Report on section of the lymph gland diagnosed reticulum cell medullary reticulosis.

30.6.48. Haemoglobin level falling rapidly.

4.7.48. Pallor now very marked, and ulcerative angina well established. The spleen and liver were larger than before.

9.7.48. Haemorrhagic gingivitis.

11.7.48. Patient died.

The clinical features of this and other reported cases are summarized in Table 1. 


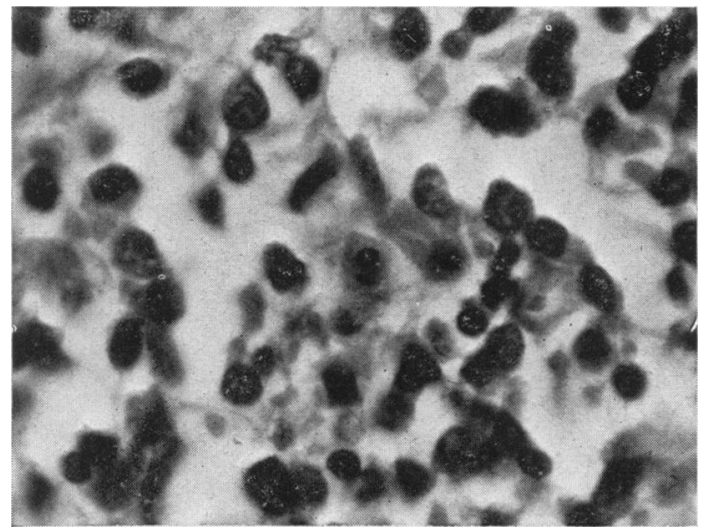

Fig. 1.-Bone marrow showing almost complete replacement by reticulum cells. Haematoxylin and eosin. $\times 675$.

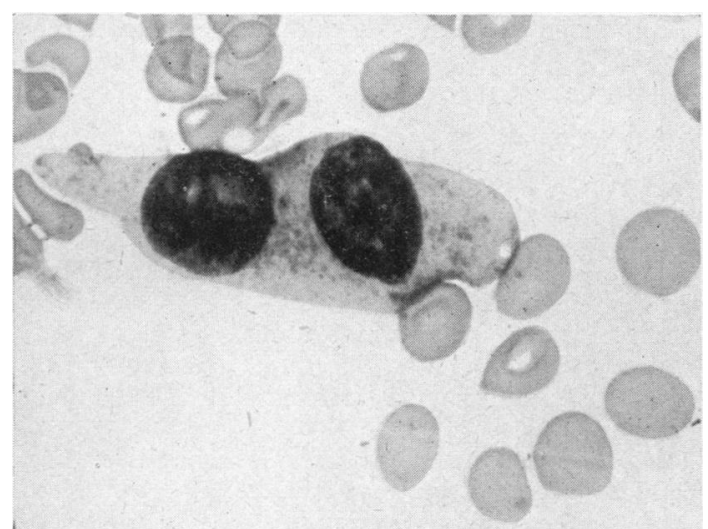

Fig. 2.-Peripheral blood smear showing binucleate form of haemohistiocyte which was present in appreciable numbers. Leishman. $\times 1200$.

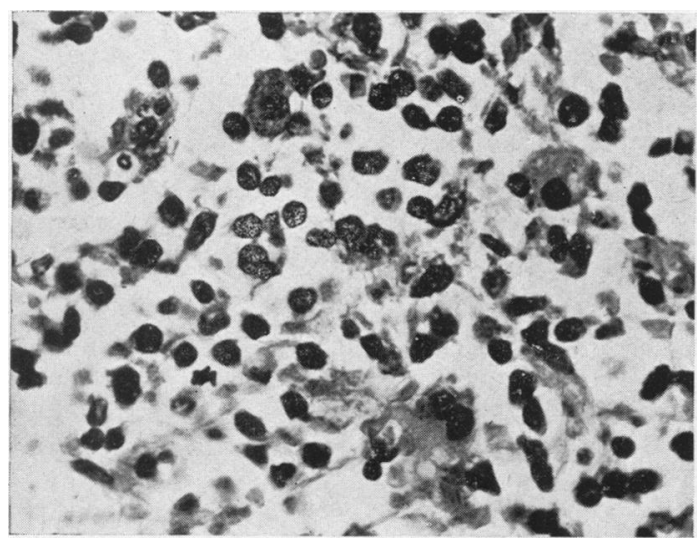

FIG. 3.-Lymph node: large numbers of reticulum cells are to be seen in the medulla. Haematoxylin and eosin. $\times 420$.

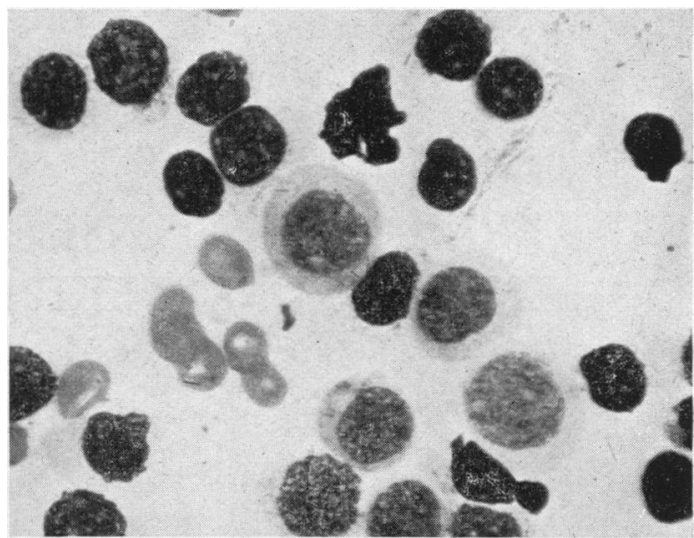

Fig. 4.-Smear of a lymph node showing large numbers of reticulum cells which are identical with the haemohistiocytes seen in Fig. 2. Leishman. $\times 675$.

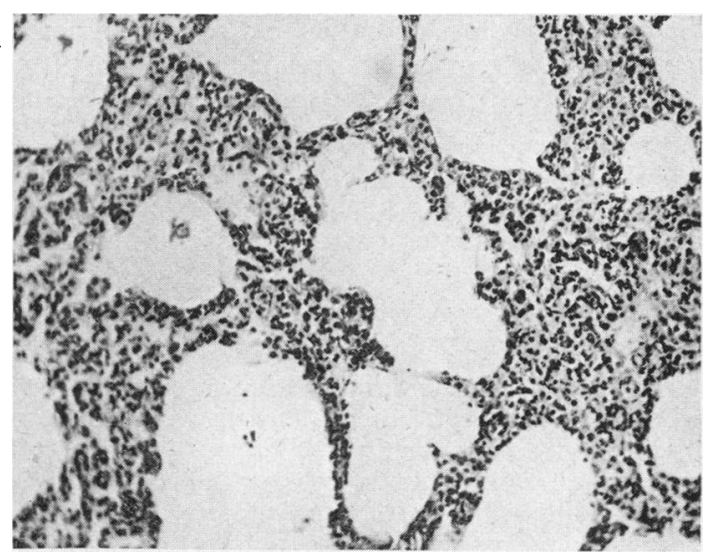

FIG. 5.-Lung showing alveolar septa markedly thickened and infiltrated by reticulum cells. Haematoxylin and eosin. $\times 100$.

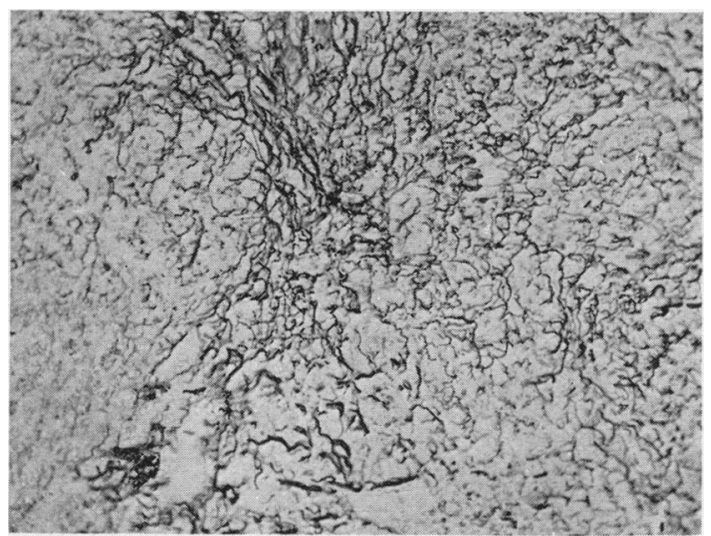

FIG. 6.-Lymph gland showing abundant formation of reticulin. Stained for reticulin. $\times 100$. 
TABLE 1

Summary of Blood findings in Present Case

\begin{tabular}{|c|c|c|c|c|c|c|c|c|c|c|}
\hline \multirow{2}{*}{\multicolumn{2}{|c|}{ Date }} & \multirow[b]{2}{*}{$\begin{array}{c}\text { R.B.C. } \\
\text { (millions } \\
\text { per c.mm.) }\end{array}$} & \multirow[b]{2}{*}{$\begin{array}{c}\text { Hb. } \\
\text { (Haldane) } \\
(\%)\end{array}$} & \multirow[b]{2}{*}{$\begin{array}{l}\text { W.B.C. } \\
\text { (millions } \\
\text { per c.mm.) }\end{array}$} & \multicolumn{6}{|c|}{ Differential White Count } \\
\hline & & & & & 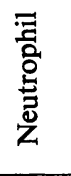 & 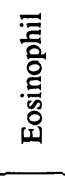 & 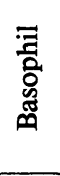 & 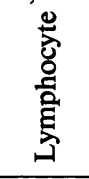 & 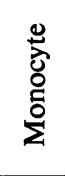 & 客 \\
\hline March & 11,1948 & $2 \cdot 3$ & 44 & 7,000 & 280 & - & - & 6,650 & - & 70 \\
\hline , & $14,,$, & $1 \cdot 6$ & 40 & 3,500 & 70 & 35 & - & 3,080 & - & 315 \\
\hline , & $21,$, & $1 \cdot 6$ & 38 & 3,900 & 195 & - & - & 3,042 & - & 663 \\
\hline \multicolumn{11}{|c|}{ Transfusion of one pint of packed cells } \\
\hline April & $1,$, & $3 \cdot 5$ & 68 & 4,000 & 360 & 40 & - & 3,520 & - & 80 \\
\hline , & $11,$, & $3 \cdot 5$ & 68 & 5,400 & 864 & - & - & 4,104 & - & 432 \\
\hline , & 18, & $2 \cdot 5$ & 48 & 5,800 & 116 & - & - & 4,698 & - & 986 \\
\hline , & $28,$, & $3 \cdot 0$ & 64 & 4,200 & 84 & - & - & 3,528 & 84 & 504 \\
\hline May & 16, & $2 \cdot 3$ & 50 & 6,500 & 130 & 65 & - & 4,875 & 65 & 1,365 \\
\hline , & $21,$, & $2 \cdot 2$ & 50 & 5,200 & 104 & 104 & - & 3,692 & 156 & 1,144 \\
\hline \multicolumn{11}{|c|}{ Transfusion of one pint of blood } \\
\hline June & 9 , , & $3 \cdot 2$ & 62 & 6,300 & 252 & - & - & 4,158 & - & 1,890 \\
\hline , & 18, & $2 \cdot 4$ & 46 & 3,100 & 124 & - & - & 2,325 & - & 651 \\
\hline \multicolumn{11}{|c|}{ Transfusion of one pint of packed cells } \\
\hline " & 25, & $3 \cdot 2$ & 62 & 3,400 & 102 & - & - & 2,720 & - & 578 \\
\hline
\end{tabular}

* The primitive cells in the peripheral blood were classed as haemohistiocytes. They were $15-25 \mu$ in diameter, having a large round reticular nucleus, a number containing nucleoli. The cytoplasm was abundant and of a pale dirty blue colour (Leishman stain).

Some cells had cytoplasmic vacuoles and others fixed pseudopodia.

\section{Post-mortem Report}

External Appearance. A very pale and emaciated male child. The oral cavity showed ulcerative angina and gingivitis.

Chest. Oesophagus. Nil.

Thymus. Small and macroscopically normal.

Pleura. Left pleural sac contained one pint of yellow fluid.

Larynx. Nil.

Lung. Trachea and bronchi normal. Lungs pale: superficial area of collapse right lower lobe.

Pericardium. Nil.

Heart. Sub-pericardial haemorrhages near the apex and in the auricles.

Valves. Nil.

Vessels. Nil.

Abdomen. Peritoneum. Nil.

Stomach. Mucosa very pale.
Duodenum. Nil.

Bile ducts. Patent.

Intestines. Peyer's patches not enlarged; solitary lymph follicles of the colon were prominent.

Lymph Nodes. The cervical, axillary, pancreaticosplenic, external iliac and inguinal glands were red and varied in size from $0 \cdot 75-1 \mathrm{~cm}$. in diameter.

Spleen. Weight, $100 \mathrm{~g}$. Cut surface dark red and firm.

Liver. Weight, 500 g. Dark terracotta colour. Structure appeared normal.

Pancreas. Nil.

Kidneys. Weight, 20 oz. Capsules stripped easily leaving a smooth surface. The cut surface was very pale.

Genito-Urinary Tract. Nil.

Brain. Very pale and macroscopically normal.

Spinal Cord. Not examined.

The sternal, vertebral, and femoral marrow was of a greyish pink colour. 


\section{Discussion}

This is a case of reticulum cell medullary reticulosis with peripheral blood changes. The white blood count fluctuated between a low normal and frank leucopenia, with the lymphocyte as the predominant cell; a fair number of haemohistiocytes were invariably present. The reticulum cells showed unmistakable differentiation in two directions, namely, haemic and histiocytic. Without a doubt the haemohistiocytes in the peripheral blood and in the marrow were similar to the proliferating reticulum cells in the lymph glands, spleen, liver, lungs, and kidney. They were medullary reticulum cells with a tendency, as far as the nuclear structure was concerned, towards haemic differentiation. Definite evidence of differentiation towards histiocytes was to be seen in the liver, spleen, lungs, kidney, and, to a lesser extent, in the lymph nodes. Apart from a few departures from the accepted picture of the Letterer-Siwe syndrome (namely, the presence of haemohistiocytes in the peripheral blood, and the absence of purpura and osseous changes) the case reported satisfies the criteria laid down by Siwe. The Wassermann and Kahn reactions were strongly positive on two occasions but negative on the third. This no doubt was due to the change in the plasma globulin.

\section{Summary}

An unusual case of reticulum cell medullary reticulosis displaying the features of the LettererSiwe syndrome is described. A tabular review of the cases reported in the literature is presented in the Appendix.

My thanks are due to Dr. B. Barling for permission to publish the case, and to Dr. A. H. T. Robb-Smith for his helpful criticism and encouragement.

\section{REFERENCES}

Abt, A. F., and Denenholz, E. J. (1936). Amer. J. Dis. Child., 51, 499.

Akiba, R. (1926). Virchows Arch., 260, 262.

Creveld, S. van, and Ter Poorten, F. H. (1935). Arch. Dis. Childh., 10, 125.

Foot, N. C., and Olcott, C. T. (1934). Amer. J. Path., 10,81 .

Gittins, R. (1933). Arch. Dis. Childh., 8, 367.

Guizetti, H. U. (1931). Virchows Arch., 282, 194.

Klostermeyer, W. (1934). Beitr. path. Anat., 93, 1.

Krahn, H. (1926). Dtsch. Arch. klin. Med., 152, 179.

Letterer, E. (1924). Z. Pathol., 30, 377.

Podvinec, E., and Terplan, K. (1931). Arch. Kinderheilk., 93, 40.

Roussy, G.. and Oberling, C. (1934). Wien. med.Wschr., 84, 407.

Sherman, I. (1929). Arch. Path., 7, 78.

Siwe, S. A. (1933). Z. Kinderheilk., 55, 212.

Uher, V. (1933). Virchows Arch., 289, 504. 


\section{A P P E N D I X}

analysis of features of Reported and Present Cases

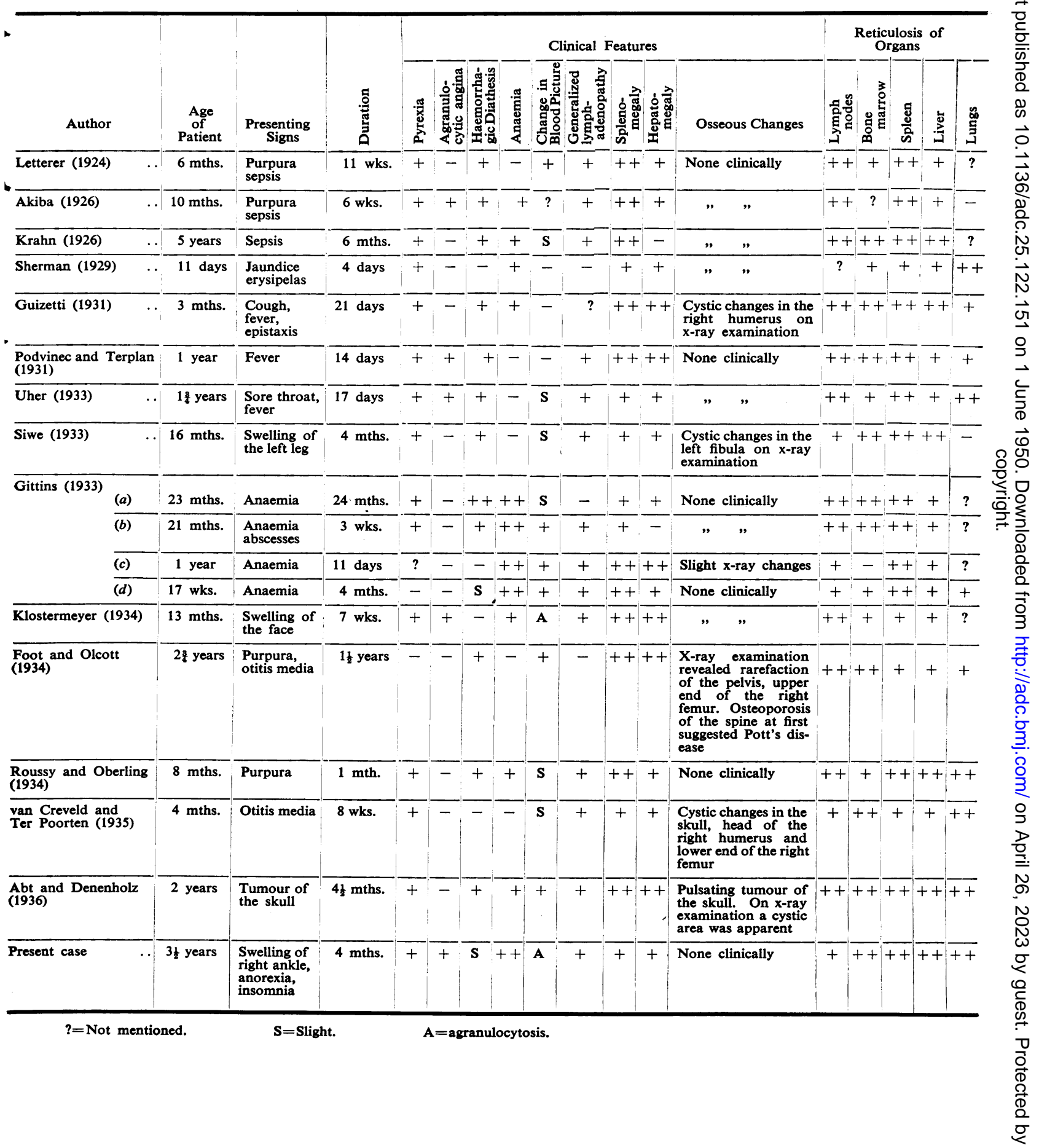

